\title{
Design of anion receptors: Applications
}

\author{
Bernard DIETRICH \\ Laboratoire de Chimie Supramoléculaire, Université Louis Pasteur, Institut Le Bel, 4 \\ rue Blaise Pascal 67000 Strasbourg (France).
}

\begin{abstract}
This paper describes binding properties of specifically designed receptors. Anion binding ligands use a large variety of binding sites (ammonium, guanidinium, Lewis acid etc); all these classes will be presented with emphasis on the binding strength and the structures of the complexes. The review is concluded by a brief survey of applications.
\end{abstract}

\section{INTRODUCTION}

The fundamental concepts exposed in the seminal paper by Lehn in 1973: Design of Organic Complexing Agents-Strategies towards Properties (ref. 1) have found abundant applications in the field of cation recognition. More recently, mainly in the last decade, this approach has been applied to the design of anionic receptors. The prerequisite of any ligand tailoring is to consider in great detail the chemical and physicochemical properties of the substrate to be bound. In the case of anions it must be recognized that compared to cations they are large, even for the monoatomic species: (anion radii in $\AA$ ), $\mathrm{F}^{-}(1.36), \mathrm{Cl}^{-}(1.81), \mathrm{Br}^{-}(1.95)$, $I^{-}$(2.16). Secondly a large variety of geometries is encountered, spherical $\left(\mathrm{F}^{-}, \mathrm{Cl}^{-}, \mathrm{Br}^{-}\right.$, $\left.\mathrm{I}^{-}\right)$, linear $\left(\mathrm{N}_{3}^{-}, \mathrm{CN}^{-}, \mathrm{SCN}^{-}\right.$etc. $)$, planar $\left(\mathrm{NO}_{3}^{-}, \mathrm{CO}_{3}{ }^{2-}, \mathrm{R}-\mathrm{CO}_{2}^{-}\right.$etc. $)$, tetrahedral $\left(\mathrm{PO}_{4}{ }^{2-}, \mathrm{SO}_{4}{ }^{2-}, \mathrm{ClO}_{4}^{-}\right)$, octahedral $\left(\mathrm{Fe}(\mathrm{CN})_{6}^{4-}, \mathrm{Co}(\mathrm{CN})_{6}^{3-}\right.$ etc.). Finally a vast number of anions exist only in a limited $\mathrm{pH}$ range, i.e., above pH 5-6 for the carboxylates (ref. 2). The ligand designer has therefore to take account of all the various anion characteristics. The size and geometry of the anion dictate the shape and size of the ligand, thus macrocyclic, macrobicyclic, macropolycyclic topologies can be used; even acyclic systems have been designed. The final and most important step in the design of the receptor is the choice of the anion binding sites which will occupy appropriate positions in the ligand. Even though interaction sites for anion binding are now numerous their development has been laborious. The ammonium and guanidinium binding sites have been the most used, but other positively charged groups like sulfonium and phosphonium have also been considered. Lewis acid functions i.e. electron-deficient centres (tin, mercury, boron, silicon) have been actively studied very recently. The use of this type of binding site leads to neutral ligands. Other anion binding sites have been explored, for example highly fluorinated macrocyclic ethers have been shown to complex fluoride anion (ref. 3a). Finally the use of the amide function (-N $\mathrm{HCO}-$ ) has been mentioned in a few reports, this function may have a promising future. In this short review the various types of anion receptors will be presented including their possible applications. Few reviews have been published devoted specifically to anion receptors (ref. $4 \mathrm{a}$ and others in the text), but several more general articles deal in part with anion complexation (ref. 4b). In particular the last excellent review by Izatt et al. gives exhaustive coverage of thermodynamic and kinetic data for anion complexation.

\section{POLYAMMONIUM MACROCYCLES}

The 18-azacrown-6 also called hexacyclen 1 has been shown to complex a large variety of anions in its tri and tetraprotonated forms. For example $1,3 \mathrm{H}^{+}$complexes polycarboxylate anions (citrate ${ }^{3-}$, succinate $2-$, malonate ${ }^{2-}$ etc.) (ref. 5a); $1,4 \mathrm{H}^{+}$complexes inorganic anions $\left(\mathrm{Cl}^{-}, \mathrm{NO}_{3}^{-}, \mathrm{Br}^{-}, \mathrm{ClO}_{4}^{-}, \mathrm{IO}_{3}^{-}\right.$etc) (ref. $5 \mathrm{~b}, \mathrm{c}$ )' The stability constants of all these complexes are weak or moderate $\left(\log \mathrm{K}_{\mathrm{s}}\right.$ from 1 to 3$)$. The sulfate anion is also complexed by both $1,3 \mathrm{H}^{+}$and $1,4 \mathrm{H}^{+}\left(\log \mathrm{Ks} \sim 2\right.$ and $\sim 4$ respectively). $\mathrm{A} 1,4 \mathrm{H}^{+}-2 \mathrm{SO}_{4}{ }^{2-}$ may also be formed (ref. 5d) and an X-ray crystallographic study on $1,4 \mathrm{H}^{+}\left(\mathrm{NO}_{3}{ }^{-}\right)_{2}\left(\mathrm{Cl}^{-}\right)_{2}$ shows that no anion is included in the central cavity (ref. 5b). A molecular mechanics study on $1,3 \mathrm{H}^{+}$has also been published (ref.

Note: i) the presentation will not follow the chronological order of discoveries; ii) due to space limitation the synthesis of the ligands will not be discussed; iii) for the same reason the rich field of interactions of anions with metal-ion centres in complexes: $\left(\mathrm{LM}^{+}\right)+\mathrm{X}^{-}=\left(\mathrm{LM}^{+}\right) \mathrm{X}^{-}$will not be treated here (ref. 3b). 


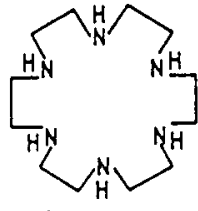

1

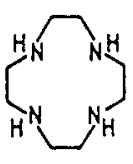

$\underline{2}$

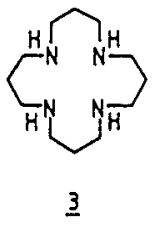

$\underline{3}$

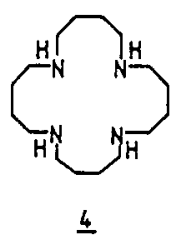

4

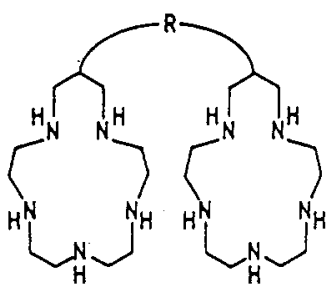

5 a $-\mathrm{CH}_{2} \mathrm{CH}_{2} \mathrm{OCH}_{2} \mathrm{CH}_{2} \mathrm{OCH}_{2} \mathrm{OH}_{2}-$ b.: $\quad-\mathrm{CH}_{2} \mathrm{CH}_{2} \mathrm{CH}_{2}-$

5c). The complexation ability of a large variety of other tetra-, penta- and hexaamines in their protonated forms have been studied and formation of complexes of phosphate anions such as inorganic phosphates, AMP, ADP, ATP has also been observed (ref. 5a). These studies and others have revealed a fundamental aspect concerning the number of protons a polyamine can accomodate at neutral $\mathrm{pH}$. This point can be illustrated by comparing three types of tetraamines 2,3 and 4 ; respectively the [12] ane $N_{4},[16]$ ane $N_{4}$ and [20]ane $\mathrm{N}_{4}$. These symmetric amines have respectively two, three or four methylene groups between two successive nitrogen atoms. The first and second protonation constants $\left(\mathrm{pK}_{1} \sim 11, \mathrm{pK}_{2} \sim 10\right)$ show only small changes but the third and fourth protonation constants exhibit large variations: $2\left(\mathrm{pK}_{3}=1.7, \mathrm{pK}_{4}<1\right), 3$ $\left(\mathrm{pK}_{3}=6.9, \mathrm{pK}_{4}=5.4\right), 4\left(\mathrm{pK}_{3}=10.6, \mathrm{pK}_{4}=8.9\right)$ (ref. 5a and 6). One can see that at neutral $\mathrm{pH}$ the [12] ane $\mathrm{N}_{4}$ can only be diprotonated, whereas [20]ane $\mathrm{N}_{4}$ is fully protonated at this $\mathrm{pH}$. These observations are not surprising since the natural tri- and tetraamines (spermidine and spermine) have both three and four carbon atoms between two successive nitrogen and are therefore fully protonated at physiological conditions which allows them to interact strongly with polyanionic nucleic acids (ref. 7). The correct spacing of successive nitrogens is therefore of primary importance in the design of anion receptors based on polyamines; it is obvious that in order to achive strong complexation highly charged ligands are desirable. It has been shown that the $4,4 \mathrm{H}^{+}$ligand binds $\mathrm{F}^{-}$(ref. 6 ) and a [18] ane $\mathrm{N}_{4}$ derivative complexes ATP4- (ref. 8a). The complexation properties of several other tetraazamacrocycles have been studied (ref. $8 \mathrm{~b}, \mathrm{c}$ ). Bis (macrocyclic polyamines) $\mathbf{5 a}$ and $\mathbf{5 b}$ in their tetra- and hexaprotonated forms were found to form $1: 1$ complexes with citrate $3-$, AMP2-, $\mathrm{ATP}^{4-}, \mathrm{HPO}_{4}{ }^{2-}, \mathrm{Fe}(\mathrm{CN})_{6}^{4-}, \mathrm{Fe}(\mathrm{CN})_{6}^{3-}$ anions. The stability constants $\left(\log \mathrm{K}_{\mathrm{s}}\right)$ of the complexes formed between the hexaprotonated $\mathbf{5 a}$ or $\mathbf{5 b}$ and tricharged anion are around 4.7 and lie between 6.2 and 7.3 for the tetracharged substrates (ref. 9).

With the aim of obtaining highly charged receptors Lehn et al, have synthesized polyamines containing six or eight nitrogens; the amine functions are separated by three methylene groups in compounds 6 and 7 , in 8 and 9 the diamine or triamine groups are separated by a five atoms unit containing no proton acceptor site (ref. 10). The ligands 6 and 8 in their hexaprotonated forms complex dianions (sulfate, oxalate, malonate,

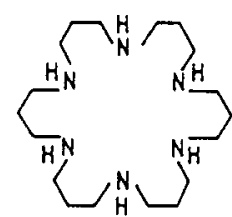

$\underline{6}$

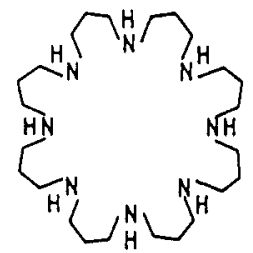

1

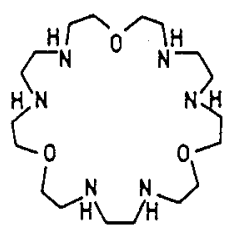

$\underline{8}$

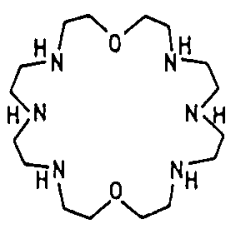

$\underline{9}$

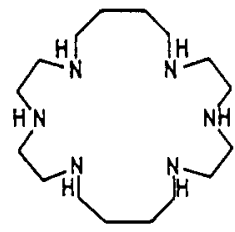

10

succinate, tartrate, AMP etc.), trianions (citrate, 1,3,5-benzenetricarboxylate, ADP, cobalt hexacyanide) and tetraanions (iron hexacyanide, ATP). The stability constants $\left(\log K_{s}\right.$ ) are high: from 2.4 to 4.7 for dianionic species; from 3.3 to 7.7 for trianionic species and from 6.3 to 9.1 for tetraanionic substrates. The octaprotonated ligand 7 forms complexes with the same anions, the stability constants are in many cases notably higher. Some structural effects are observed; for example the large anions are very strongly complexed by the large 7,8 $\mathrm{H}^{+}$ligand. A detailed study by ${ }^{31} \mathrm{P}-\mathrm{NMR}$ spectroscopy on AMP, ADP, ATP nucleotides binding by the protonated ligands $6,7,9$ has revealed that 6 and 9 form $1: 1$ complexes whereas in some cases 7 binds two nucleotides (ref. 11). Crystal structures of two hexaaza macrocycles 9 and 10 as their hexahydrochloride salts have been determinated. In the case of $9,6 \mathrm{H}^{+}$a strong interaction is observed with one chloride ion. whilst two chlorides are seen to be more weakly bound. In $10,6 \mathrm{H}^{+}$two $\mathrm{Cl}^{-}$are bound above and below the mean plane of the macrocycle, each of them by a group of three ammonium units (ref. 12). The macrocycle 9 has been attached to a polymer; the bound macrocycle having a high affinity for ATP (ref. 13). Long aliphatic chains have been attached to the macrocycle 9 and other hexaaza macrocycles; these compounds will certainly allow efficient extraction of anions (ref. 14). Very large macrocycles containing seven to twelve amine functions have been synthesized and despite the fact that the amines are separated by only two methylene groups they can be very highly protonated in the neutral pH region (ref. 15). The complexation of complex anions $\left(\mathrm{Fe}(\mathrm{CN}) 6^{4-}, \mathrm{Co}(\mathrm{CN}) 6^{3-}, \mathrm{Pt}(\mathrm{CN}) 4^{2-}\right.$ etc) leading to complexes of 


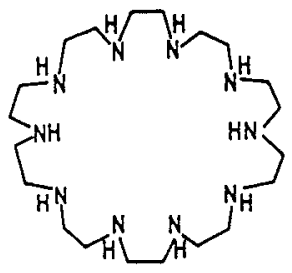

$\underline{11}$

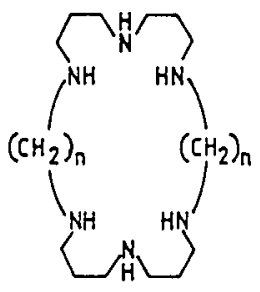

$\underline{12} n=7 ; 10$<smiles></smiles>

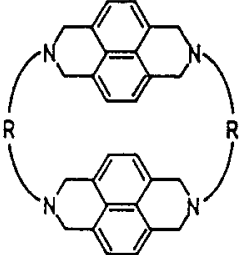

$14 \mathrm{R}=\left(\mathrm{CH}_{2}\right)_{8}$

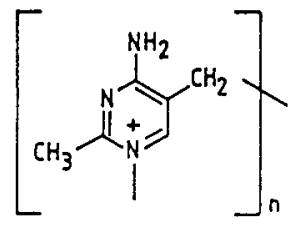

$15 n=4 ; 6$

complexes (or "supercomplexes," or second-sphere coordination) has been studied alsmost exclusively. Since the number of protonated forms able to form complexes is very large (depending the ligand from $\mathrm{LH}_{3}{ }^{3+}$ up to $\mathrm{LH}_{11} 11+$ ) a wide range of stability constants are observed (from $\log \mathrm{K}_{\mathrm{S}} \sim 3$ up to 9) (ref. 16). Several crystal structures of complexes formed with the ligand [30] ane $\mathrm{N}_{10}, 11$ (anions being $\mathrm{Co}(\mathrm{CN}) 6^{3-}$, $\mathrm{Pt}(\mathrm{CN})_{4}^{2-}, \mathrm{Pt} \mathrm{Cl}_{6}{ }^{2-}$ ) show that the anions are located outside the cavity (ref. 15, 16), but with $\mathrm{PdCl}_{4}{ }^{2-}$ the anion is held inside the receptor cavity (ref. 17). The formation of supercomplexes by ligands 6,7 and 11 with complex anions $\left(\mathrm{Fe}(\mathrm{CN}) 6^{4-}, \mathrm{Fe}(\mathrm{CN}) 6^{3-}, \mathrm{Co}(\mathrm{CN}) 6^{3-}, \mathrm{Ru}(\mathrm{CN}) 6^{4-}\right.$, very strongly affects the redox behaviour of the bound anions as well as their photochemical properties. These two aspects have been very actively studied (ref. 18). A class of ditopic polyamine macrocycles 12 has been synthesized containing two triamine subunits each able to bind one carboxylate group. These compounds can therefore complex, in their protonated forms, dicarboxylate anions $-\mathrm{O}_{2} \mathrm{C}-\left(\mathrm{CH}_{2}\right)_{\mathrm{m}}-\mathrm{CO}_{2}-$. Each receptor 12 binds preferentially the best adapted dicarboxylates $(\mathrm{m}=2$ and 3 for $\mathrm{n}=7 ; \mathrm{m}=5$ and 6 for $\mathrm{n}=10$ ) (ref. 19). Polyaza macrocycles incorporating pyridine have also been synthesized, the hexaprotonated dipyridino-28-crown-8, 13 forms complexes with $\mathrm{SeO}_{4}{ }^{2-}$ and $\mathrm{SO}_{4}{ }^{2-}\left(\log \mathrm{K}_{\mathrm{S}} \sim 3.5\right)$ (ref. 20$)$. A ligand 14, designed to form complexes of an intercalative type has been synthesized. In its tetraprotonated form 14 binds flat anions like 1,4-benzene dicarboxylate and 2,6-naphtalene dicarboxylate $\left(\log \mathrm{K}_{\mathrm{s}} \sim 4\right)$ (ref. 21). Macrocycles containing pyrimidinium units 15, have been described. The quaternization of the N1 nitrogens results in an overall charges of $4^{+}$for $\mathrm{n}=4$ and $6^{+}$for $\mathrm{n}=6$. The small [16-pyrimidinium crown-4 $]^{4+}$ binds $\mathrm{Cl}^{-}$and $\mathrm{NO}_{3}^{-}$, the larger [24pyrimidinium crown-6] ${ }^{6+}$ binds $\mathrm{HgI}_{3}{ }^{-}$and $\mathrm{HgI}_{4}{ }^{2-}$; crystal structures of these complexes have been established (ref. 22).

An expanded porphyrin, sapphyrin 16 has revealed surprising anion binding properties. Crystal structure of $\left(16,2 \mathrm{H}^{+}, \mathrm{F}^{-}, \mathrm{PF}_{6}^{-}\right)$shows that the anion is located in the central core of the ligand (ref. 23a). The lipophilicity of 16 allows through-membrane transport of fluoride (ref. 23b) and nucleotide monophosphates (ref. 23c). Finally it has been demonstrated by FAB mass spectrometry that a hexaprotonated porphyrin trimer 17, binds very large anions like $\mathrm{PW}_{12} \mathrm{O}_{40}{ }^{3-}, \mathrm{SiW}_{12} \mathrm{O}_{40}{ }^{4-}$ and $\mathrm{Os}_{10} \mathrm{C}(\mathrm{CO})_{24}{ }^{2-}$ (ref. 24).

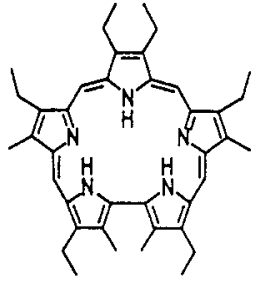

16

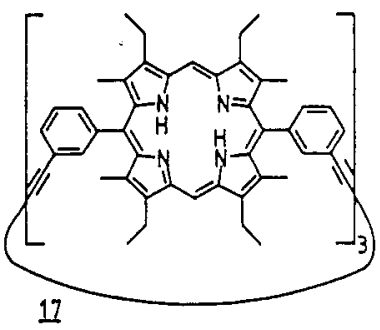

17

\section{POLYAMMONIUM MACROBICYCLES}

The first class of purely organic ligands, 18, has been described by Park and Simmons (ref. 25). The inclusion of halides was suggested by NMR studies and has been confirmed by the crystal structure of the diazabicyclo [9.9.9.], $2 \mathrm{H}^{+}, 2 \mathrm{Cl}^{-}$in which one $\mathrm{Cl}^{-}$is located in the centre of the cavity (ref. 26). Other ligands containing two binding sites have also been described (ref. 4b). A first series of macrobicyclic receptors 19 having six or eight protonable nitrogens have been synthesized (ref. 27). Complexation has been evidenced by NMR and analysis of the $\mathrm{pH}$-metric titration curves (ref. 28). For the ligand $19 \mathrm{a}, 6 \mathrm{H}^{+}$ some examples of stability constants $\left(\log \mathrm{K}_{\mathrm{S}}\right)$ are : $\mathrm{F}^{-}(4.1), \mathrm{Cl}^{-}(3.0), \mathrm{N}_{3^{-}}(4.3)$, oxalate ${ }^{-}(4.95), \mathrm{SO}_{4}{ }^{2-}$

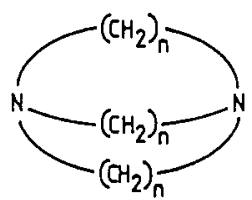

18

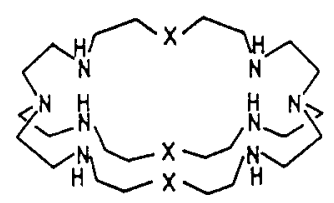

19 a $X=0 ;$ b $X=\mathrm{CH}_{2}$

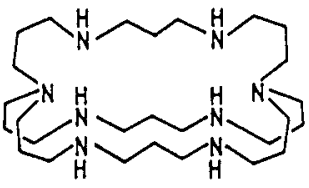

$19 c$

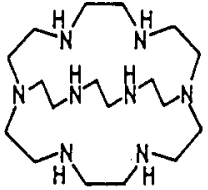

20 
(4.9), $\mathrm{HPO}_{4}$ 2- (5.5.), AMP2- (3.85), ADP3- (5.85), ATP4- (8.0), $\mathrm{P}_{2} \mathrm{O}_{7} 4-(10.3)$ (ref. 28b). At low pH 19a, $6 \mathrm{H}^{+}$and $19 \mathrm{~b}, 6 \mathrm{H}^{+}$bind also the $\mathrm{HF}^{2-}$ anion (log $\mathrm{K}_{\mathrm{s}}$ respectively 6.4 and 5.2 ) (ref. 29). Crystal structures of four anion complexes $\left(\mathrm{F}^{-}, \mathrm{Cl}^{-}, \mathrm{Br}, \mathrm{N}_{3}^{-}\right)$of the $19 \mathrm{a}, 6 \mathrm{H}^{+}$ligand show: i) that all the complexes are of cryptate type; ii) that the ligand is far too large for $\mathrm{F}^{-}$; iii) that the linear triatomic $\mathrm{N}_{3}$ - fits perfectly in the ellipsoïdal cavity (ref. 28b). The compound 19c can accomodate eight protons, therefore the stability constants $\left(\log \mathrm{K}_{\mathrm{S}}\right)$ are quite strong: oxalate ${ }^{2-}(6.55), \mathrm{SO}_{4}{ }^{2-}(7.45)$ (ref. 30$)$. The octaazacryptand 20 has been designed for selective binding of $\mathrm{F}^{-}$; the crystal structure confirms that the cavity is well adapted for this anion (ref. 31). Several ligands 21 containing aromatic rings have been designed and synthesized. The three hexaprotonated ligands form stable complexes with monovalent ions: $\mathrm{Cl}^{-}, \mathrm{NO}_{3}{ }^{-}, \mathrm{N}_{3}{ }^{-}\left(\log \mathrm{K}_{\mathrm{S}}\right.$ lie in the range $2.5-4)$ and dianions: sulfate, oxalate $\left(\log \mathrm{K}_{\mathrm{S}} 5.0-6.5\right)$. The complexation of the nitrate anion by $21 \mathrm{a}, 6 \mathrm{H}^{+}$ has some unusual features: in solution the NMR studies show a very clear 1:1 stoichiometry which supports the inclusion of one nitrate in the cavity; in contrast to this conclusion the solid state reveals that no anion is held in the cavity. It seems that in order to provide hydrogen bonding of the outside anions in the solid state an outside orientation of the $\mathrm{NH}_{2}+$ sites occurs. In aqueous solution the external anions can be well enough solvated by the solvent and therefore an inside orientation of the $\mathrm{NH}_{2}+$ units is possible and leading to the complexation of one nitrate (ref. 32). The cyclophane type macrobicycle 22 has been obtained in high yield in few steps (ref. 33a). The $22,6 \mathrm{H}^{+}$binds many dicarboxylates $\left(\log \mathrm{K}_{\mathrm{s}}\right.$ from 3.15 to 4.4 ). The crystal structure of the complex formed with the terephtalate anion shows the good receptor/substrate complementarity (ref 33b).

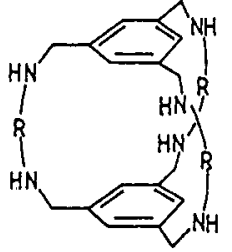

$212 \mathrm{R}=-\left(\mathrm{CH}_{2}\right)_{3}-$

$216 \mathrm{R}=-\mathrm{CH}_{2} \mathrm{CH}_{2} \mathrm{OCH}_{2} \mathrm{CH}_{2}-$

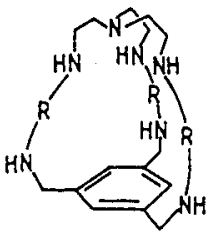

21C $\mathrm{R}=-\mathrm{CH}_{2} \mathrm{CH}_{2} \mathrm{OCH}_{2} \mathrm{CH}_{2}$

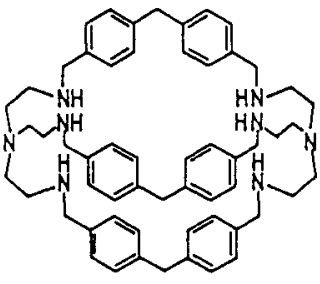

$\underline{22}$

\section{POLYAMMONIUM MACROTRICYCLES}

The aesthetically pleasing macrotricyclic ligand 23 has been described (ref. 34). Spherical anions (halides) are complexed by $23,4 \mathrm{H}^{+}$; a remarkable $\mathrm{Cl}^{-} / \mathrm{Br}^{-}$selectivity $\left(>10^{3}\right)$ being observed (ref. 35). The crystal structure of the chloride complex shows that the enclosed $\mathrm{Cl}^{-}$is bound by a tetrahedral array of $\mathrm{N}-\mathrm{H}^{+} \ldots \mathrm{X}-$ hydrogen bonds (ref. 36). Detailed ${ }^{35} \mathrm{Cl}-\mathrm{NMR}$ investigations of this and several other chloride binding macrobicyclic ligands described in the preceding section have been performed. This type of study allows: i) the direct observation of the complexed anion; ii) the unambigous determination of the stoichiometry; iii) competition experiments between $\mathrm{Cl}^{-}$and other anion, i.e. determination of the relative stabilities of different anion complexes (ref. 37). Molecular modelling studies on the $23,4 \mathrm{H}^{+}$system give insight into the structural organization of the receptor. It has been shown for example that in the most stable conformation of the uncomplexed $23,4 \mathrm{H}^{+}$receptor the $\mathrm{NH}^{+}$units are directed toward the inside of the cavity, i.e. the binding sites are well oriented prior to complexation (ref. 38). Several macrotricyclic ligands

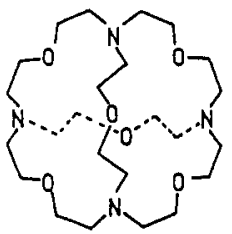

$\underline{23}$

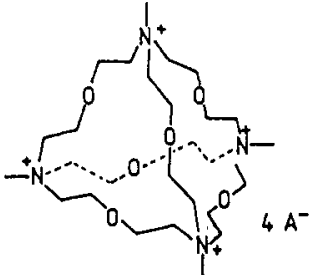

$\underline{24 a}$

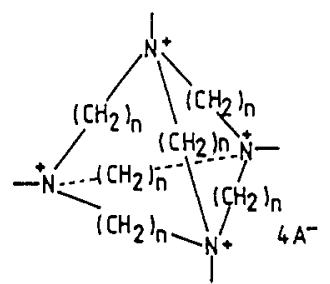

$\underline{24 b} n=6 ; \underline{24 c} n=8$

24 of similar topology but containing quaternary ammonium salt as binding site have been described (ref. 39 a). Compared to $\mathbf{2 3}$ the stability constants of the complexes formed between 24 and halides are weak and the selectivity order is reversed $\mathrm{Br}^{-}>\mathrm{Cl}^{-}$(ref. 39b). An X-ray study on $\mathbf{2 4 b}$. I- clearly shows the encapsulation of the anion (ref. 39c). A ditopic ligand containing the two macrotricyclic units $24 \mathbf{b}$ and $24 \mathrm{c}$ connected by a paraxylene bridge has been described and some selectivity in binding of difunctional anions was observed (ref. 40). To conclude this section on polyammonium anion receptors it has to be mentioned that as in the case of cation receptors there are macrocyclic, macrobicyclic and macrotricyclic effects (ref. 41, 35). Finally some ditopic ligands containing one binding unit for anion and another for cation have been described. One example combines a polyaza-macrocycle with a macrocyclic polyether, the two units being linked covalently (ref. 42). Another ditopic ligand, a macrobicyclic system, contains on one side of the cavity three quaternary ammonium and on the other side three carboxylic acid functions (ref. 43). The two types of ditopic receptors bind amino-acids. 


\section{GUANIDINIUM}

Guanidinium has at first glance several interesting features: i) the high protonation constant of guanidine (pK $\sim$ 13.5) eliminates one of the major problems encountered in the polyamines series, i.e. guanidinium exists over almost the full range of the $\mathrm{pH}$ scale; ii) guanidinium and the partially substituted derivatives can form many zwitterionic hydrogen bonds $\mathrm{N}-\mathrm{H}^{+} \ldots \mathrm{X}^{-}$. Of particular interest is the formation of pairs of hydrogen bonds with anions in which the negative charge is delocalized over several atoms, carboxylates, phosphates etc. This type of ion pairing (secured by the guanidinium group of arginyl residues) is largely found in proteins (ref. 44). The use of a guanidinium binding site for anion receptors was explored quite early by Lehn et al. (ref. 45a). One example, the triguanidinium macrocycle 25 binds $\mathrm{PO}_{4}{ }^{3-}$ - but the stability constant is low $\left(\log K_{s}=2.4\right)$. Several explanations for this weak complexation can be put forward: a limited number of binding sites, ligand conformation leading to unadapted configuration of the guanidinium moiety i.e. there is no good possibility of forming pairs of hydrogen bonds. The poor binding properties of these systems combined with their cumbersome synthesis have apparently alienated further research in this direction and efforts have been focused on acyclic ligands. Several non-cyclic di-, tri- and tetraguanidinium (for example, propylene diguanidinium, tris(ethyleneguanidinium)amine, ethylenediamine tetrakis(ethylene guanidinium)), have been described. These ligands form relatively stable complexes with many phosphate and carboxylate anions (ref. $45 \mathrm{~b}$ ). With the aim of maintaining a favourable orientation of the two hydrogen atoms, the guanidinium group has been incorporated into a bicyclic system 26; compounds $26, \mathbf{a}, \mathbf{b}, \mathbf{c}$ have been shown by NMR studies to complex p-nitrobenzoate, phosphate etc. (ref. 46a). The crystal structure of the

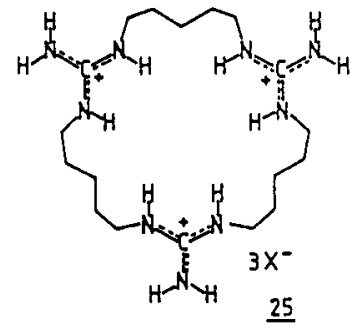

$\underline{25}$

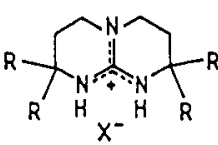

$26 \mathrm{a} R=\mathrm{CH}_{3}$

b. $\mathrm{R}=\mathrm{CH}_{2} \mathrm{CH}_{2} \mathrm{CH}_{2}$

s. $\mathrm{R}=\mathrm{CH}_{2} \mathrm{CH}_{2} \mathrm{CH}_{2} \mathrm{OH}$

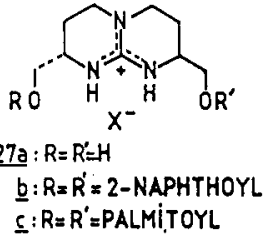

$\underline{c}: R=R^{\prime}=P A L M I T O Y L$

d : $R=2-$ NAPHTHOYL $R^{\prime}=\mathrm{COCH}_{2}$ NMONOAZA -

18-CROWN-6)

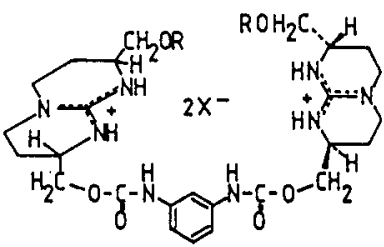

28

26c acetate demonstrates as expected that the acetate anion is bound, via two hydrogen bonds, to the guanidinium unit (ref. 46a). In a further step in complexity the disubstituted derivatives 27a have been synthesized independently in two laboratories (ref. $46 \mathrm{~b}$ ). The $Q$-substituted derivatives of $27 \mathbf{b}, \mathbf{c}$ of the $\underline{S . S}$ and $\mathrm{R}, \mathrm{R}$ enantiomers have been shown to extract anions (aromatic carboxylates, adenine monophosphate nucleotides) from water to chloroform, in some cases chiral recognition is observed (ref. 46c). A non-cyclic ditopic receptor 28 has also been described and shown to extract dicarboxylates (succinate, fumarate etc) from water to chloroform (ref. 46d). Chiral receptors derived from 27a S.S and $\underline{R . R}$ have been designed for amino-acid recognition; these compounds $27 \mathrm{~d}$ extract (from water to methylene chloride) mainly tryptophan and phenylalanine. A high degree of chiral recognition is achieved, 27d $\underline{\text { S.S }}$ extracts the L enantiomers, 27d R,R the D enantiomers (ref. 46e).

\section{AMIDE FUNCTION}

Several recent X-ray structures of anion binding proteins have revealed that many amide protons $\mathrm{CO}-\mathrm{NH}$ are involved in the binding of inorganic oxyanions (sulfate, phosphate) (ref. 47). It should therefore be possible to consider this type of binding site in the design of anion receptors. Reports on this class of ligand are scarce. Ten years ago Kimura mentioned the possibility that in the dioxo pentamine 29a in addition to the ammonium sites the two amide protons may be involved in phosphate binding (ref. $48 \mathrm{a}$ ). The same author reported later that the dimethyl derivative $29 \mathrm{~b}$ of this compound forms a $2: 2$ complex (dimer sandwich) with $\mathrm{N}_{3}$ and the X-ray structure shows that amide NH's are interacting with the two anions (ref. 48b). A macrobicyclic ligand, 30, containing three amide bonds has been designed; NMR studies (in DMSO) may suggest binding of fluoride (ref. 48c). An acyclic receptor of tripod-type containing three amides linked to three positively charged cobalticinium complexes the $\mathrm{Cl}^{-}$and $\mathrm{Br}$ anions; NMR studies indicate $\mathrm{CONH} \cdot \mathrm{X}^{-}$hydrogen bonds (ref. 48d). The major drawback of the CONH unit is the difficulty of handling this binding site in a highly structured framework (macrocyclic, macropolycyclic systems) because of the quite rigid directionality of the amide $\mathrm{NH}$ moiety.

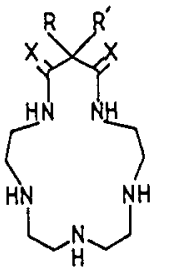

$\underline{29}$

a) $X=0 ; R=R^{\prime}=H$

b) $X=0 ; R=R^{\prime}=\mathrm{CH}_{3}$

c) $X=H_{2} ; R=H, R^{\prime}=\mathrm{C}_{16} \mathrm{H}_{33}$

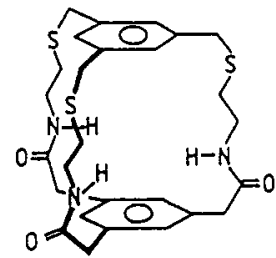

$\underline{30}$ 


\section{LEWIS ACIDS}

The new field of anion receptors based on Lewis acids as binding site is growing rapidly. Compared to the vast majority of ligands described above the biggest advantage of this new class is the possibility of having neutral receptors. The tin-macrocycles were the first reported compounds: distannacycloalkanes (ring size 10 - 26) and tetrastannacycloalkanes (ring size 20-52) as well as distannamacrobicycles (ref. 49a). Chloride complexation by the ligands 31 has been studied in acetonitrile by $119 \mathrm{Sn}-\mathrm{NMR} ; 1: 1$ and $1: 2 \mathrm{ligand} / \mathrm{Cl}^{-}$ stoichiometries are found (log Ks in the range $2.7-2.9$ ) (ref. 49b). Distannamacrobicycles 32 bind only one halide, this suggests an encapsulation of the anion (ref. $49 \mathrm{c})$. The smallest receptor $(n=6)$ binds fluoride (ref. 49d). The inclusion of $\mathrm{F}^{-}\left(\right.$in $32 \mathrm{n}=6$ ) and $\mathrm{Cl}^{-}$(in $32 \mathrm{n}=8$ ) has been confirmed by $\mathrm{X}$-ray structures (ref. $49 \mathrm{e}$ ). The stability constants for all the macrocycles or macrobicycles described are moderate or weak (ref. 49f). In order to obtain a higher anion binding strenght a four tin-containing macrocyclic receptor has been synthesized. This ligand complexes chloride with a 1:1 ratio and as expected the stability constant is somewhat higher (ref. $49 \mathrm{~g}$ ). A class of boron-containing ligands 33 has been described and the complexation of $\mathrm{H}^{-}$by $33 \mathrm{a}$ has been established; this complex having a high chemical stability. Its crystal structure reveals that the hydride is bridged unsymmetrically between the two boron atoms (ref. 50a). The derivate 33b binds $\mathrm{Cl}^{-}$, as above, a bridging of the anion is observed (ref. 50b). Mixed 1,8-naphthalene derivatives $33 \mathrm{c}$ containing boron and silicon also bind F- (ref. $50 \mathrm{c}$ ). Silicon has been incorporated in a macrocyclic framework; the 12-silacrown-3 34 transports anions ( $\mathrm{Cl}-, \mathrm{Br}$ ) accross an organic layer (ref. 51). Finally mercury has also been considered. A [12] mercurycarborand-4 complexes $\mathrm{Cl}^{-*}$ the $\mathrm{X}$-ray structure shows that the anion is bound to the four mercury centres in a highly surprising almost squareplanar coordination (ref. 52).

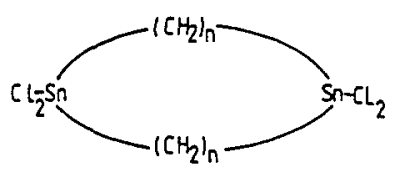

$\underline{31}$

$n=8,10,12$

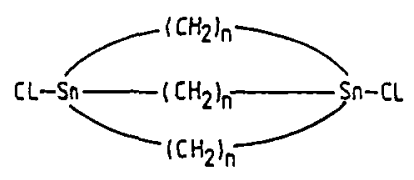

32

$n=6,8,10,12$

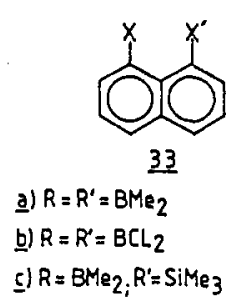

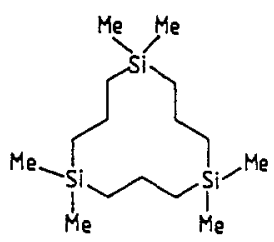

$\underline{34}$

\section{APPLICATIONS}

In this last section a rapid survey of the major applications of anion receptors will be given. The first areas of interest are the extraction and transport of anions. The extractor or carrier have to fulfil two requirements, namely to be good complexing agents and exhibit high lipophilicity (ref. 53a). A very simple system has been largely used, it consists of the diquaternary ammonium derivative of the 1,4-diazabicyclo [2.2.2.]octane (DABCO), the high lipophilicity is obtained by the symmetrical attachment of long aliphatic chains $\left(\mathrm{C}_{18}\right.$ for example). This compound transfers nucleotide anions from aqueous solution to chloroform; high selectivity ratios are observed, the relative order of extraction is tri- $>$ di- $>$ monophosphate; these nucleotides can also be transported through a chloroform membrane (ref. 53b). Based on the same DABCO unit systems containing more quaternary ammonium sites (three or four) have also been elaborated, they show interesting transport properties (ref, 53c). Several lipophilic polyaza macrocycles have been demonstrated to be good carriers for polycarboxylate anions and amino-acids (ref. 54a). The hexatosylated macrobicycle $19 \mathrm{a}, 2 \mathrm{H}^{+}$ acts as transporter for inorganic anions ( $\mathrm{Cl}^{-}, \mathrm{Br}$ ) across a chloroform membrane (ref. 54b). The lipophilic pentamine $29 \mathrm{c}$ has been incorporated into a polymeric membrane allows the construction of an anion sensor which exhibit high sensitivity to the ATP4- and HATP3- anions (ref. 54c). The large variety of anion receptors available will certainly induce further efforts in the construction of sensors. The macrocycle 9 has found very important applications in the field of molecular catalysis. Notably it catalyses very efficiently ATP hydrolysis: i) compared to the uncatalyzed reaction the rate of acceleration at $\mathrm{pH}=8.5$ is around $10^{3}$, ii) this high rate stays constant over a very large range of $\mathrm{pH}$ (from 2.5 up to 8.5 ) (ref. 55a). In addition, compound 9 has been found to allow bond formation: during the hydrolysis of acetylphosphate in presence of 9 formation of pyrophosphate was observed resulting from the reaction of a phosphorylated intermediate of the macrocycle with phosphate $(55 \mathrm{~b})$. The macrotricycles 24 have also found many applications in molecular catalysis (ref. 55c). Macrocyclic polyamines have found applications outside chemistry. Muscle actin polymerizes reversibly in the presence of natural polyamines (spermine, spermidine), this transformation is highly enhanced in the presence of compounds such as 7, 9, 12 (ref. 56). Macrocycles [18]ane $\mathrm{N}_{6}$ and [16] ane $\mathrm{N}_{5}$ have been shown to be able to dissolve urinary calculi which contain as major components calcium phosphate and calcium oxalate; the anion complexation seems to be the driving force of this solubilization (ref. 57).

This short review, by no means exhaustive, shows that anion complexation is now a full member of the field of supramolecular chemistry (ref. 58).

\section{Acknowledgements}

I wish to warmly thank Professor J.-M. Lehn for the exciting quarter of a century I have passed in his research group. The author acknowledges the CNRS for financial support. 


\section{REFERENCES}

1. J.-M. Lehn, Structure and Bonding 16, 1 (1973).

2. B. Dietrich, Inclusion Compounds vol. 2, p. 337, Academic Press (1984).

3. a) W.B. Farnham, D.C. Roe, D.A. Dixon, J.C. Calabrese, R.L. Harlow, J. Am. Chem. Soc. 112, 7707-7718 (1990). b) M. Micheloni, P. Paoletti, S. Bürki, T.A. Kaden, Helv. Chim. Acta 65, 587594 (1982); S.M. Nelson, Inorg. Chim. Acta 62, 39-50 (1982); J.E. Bulkowski, W.E. Summers III, Copper Coordination Chemistry: Biochemical and Inorganic Perpectives p. 445, Adenine Press (1983); Y.L. Agnus, ibid, p. 371; R.J. Motekaitis, A.E. Martell, B. Dietrich, J.-M. Lehn, Inorg. Chem. 23 , 1588-1591 (1984); R.J. Motekaitis, A.E. Martell, I. Murase, Inorg. Chem. 25, 938-944 (1986); R.D. Hancock, A.E. Martell, Chem. Rev 89, 1875-1914 (1989); A.E. Martell, R.J. Motekaitis, Coord. Chem. Rev. 100, 323-361 (1990).

4. a) J.L. Pierre, P. Baret, Bull. Soc. Chim. France 367-380 (1983); F.P. Schmidtchen, Nachr. Chem. Tech. Lab. 36, 8-17 (1988). b) F. Vögtle, H. Sieger, W.M. Müller, Topics in Current Chemistry 98, 107-161 (1981); P.G. Potvin, J.-M. Lehn, Synthesis of Macrocycles: The Design of Selective Complexing Agents p. 167 Wiley (1987); J.-M. Lehn, Angew. Chem. Int. Ed. Engl, 27, 89-112 (1988); R.M. Izatt, K. Pawlak, J.S. Bradshaw, R.L. Bruening, Chem. Rev. 21, 1721-2085 (1991).

5. a) E. Kimura, Topics in Current Chemistry 128, 113-141 (1985); b) J. Cullinane, R.I. Gelb, T.N. Margulis, L.J. Zompa, J. Am. Chem Soc. 104, 3048-3053 (1982); c) R.I. Gelb, B.T. Lee, L.J. Zompa, J. Am. Chem. Soc. 107, 909-916 (1985); d) R.I. Gelb, L.M. Schwartz, L.J. Zompa, Inorg. Chem. 25, 1527-1535 (1986); d) M.A. Santos, M.G.B. Drew, J. Chem. Soc. Faraday Trans. 13211331 (1991).

6. E. Suet, H. Handel, Tetrahedron Lett. 25, 645-648 (1984).

7. S. Bunce, E.S.W. Kong, Biophys. Chem. 8 , 357-368 (1978); M.D. Bratek-Wiewiorowska, M. Alejska, M. Figlerowicz, J. Barciszewski, M. Wiewiorowski, M. Jaskolski, W. Zilenkiewicz, A. Zielenkiewicz, M. Kaminski, Pure and Appl. Chem. 59, 407-414 (1987).

8. a) A. Bianchi, M. Micheloni, P. Paoletti, Inorg. Chim. Acta 151, 269-272 (1988); b) J.F. Marecek, C.J. Burrrows, Tetrahedron Lett. 27, 5943-5946 (1986); c) J.S. Alper, R.I. Gelb, M. Schwartz, J. Incl. Phen. Mol. Recogn. Chem. 11, 333-348 (1991); ibid, 349-360.

9. E. Kimura, Y. Kuramoto, T. Koike, H. Fujioka, M. Kodama, J. Org. Chem. 55, 42-46 (1990).

10. B. Dietrich, M.W. Hosseini, J.-M. Lehn, J. Am. Chem. Soc. 103, 1282-1283 (1981) and Helv. Chim. Acta 66, 1262-1278 (1983).

11. M.W. Hosseini, J.-M. Lehn, Helv. Chim. Acta 70, 1312-1319 (1987).

12. S. Boudon, A. Decian, J. Fischer, M.W. Hosseini, J.-M. Lehn, G. Wipff, J. Coord. Chem. 23, 113135 (1991).

13. D. Cordier, M.W. Hosseini, New J. Chem. 14, 611-616 (1990).

14. G. Brand, M.W. Hosseini, R. Ruppert, Helv. Chim. Acta 75, 721-728 (1992).

15. A. Bianchi, M. Micheloni, P. Paoletti, Pure and Appl. Chem. 60, 525-532 (1988).

16. A. Bencini, A. Bianchi, P. Dapporto, E. Garcia-Espana, M. Micheloni, J.A. Ramirez, P. Paoletti, P. Paoli, Inorg. Chem. 31, 1902-1908 (1992).

17. A. Bencini, A. Bianchi, M. Micheloni, P. Paoletti, P. Dapporto, P. Paoli, E. Garcia-Espana, J. Incl. Phen. Mol. Recogn. Chem. 12, 291-304 (1992).

18. V. Balzani, N. Sabbatini, F. Scandola, Chem. Rev. 86, 319-337 (1986); J. Arago, A. Bencini, A. Bianchi, A. Domenech, E. Garcia-Espana, J. Chem. Soc. Dalton Trans. 319-324 (1992); M.W. Hosseini, Perspectives in Coordination Chemistry p. 333, VCH (1992).

19. M.W. Hosseini, J.-M. Lehn, Helv. Chim. Acta 69, 587-603 (1986).

20. G. Wu, R.M. Izatt, M.L. Bruening, W. Jiang, H. Azab, K.E. Krakowiak, J.S. Bradshaw, J. Incl. Phen. Mol. Recogn. Chem. 13, 121-127 (1992).

21. J. Jazwinski, A.J. Blacker, J.-M. Lehn, M. Cesario, J. Guilhem, C. Pascard, Tetrahedron Lett. 28 , 6057-6060 (1987).

22. R.E. Cramer, M.J.J. Carrié, Inorg. Chem. 29, 3902-3904 (1990); R.E. Cramer, V. Fermin, E. Kuwabara, R. Kirkup, M. Selman, J. Am. Chem. Soc. 113, 7033-7034 (1991).

23. a) J.L. Sessler, M.J. Cyr, V. Lynch, E. McGhee, J.A. Ibers, J. Am. Chem. Soc. 112, 2810-2813 (1990); b) J.L. Sessler, D.A. Ford, M.J. Cyr, H. Furuta, J. Chem. Soc. Chem. Comm. 1733-1735 (1991); c) H. Furuta, M.J. Cyr, J.L. Sessler, J, Am. Chem. Soc. 113, 6677-6678 (1991).

24. H.L. Anderson, J.K.M. Sanders, J. Chem. Soc. Chem. Comm. 946-947 (1992).

25. C.H. Park, H.E. Simmons, J. Am. Chem. Soc. 90 , 2431-2432 (1968); H.E. Simmons, C.H. Park, R.T. Uyeda, M.F. Habibi, Trans. N-Y Acad. Sci. $32,521-534$ (1970).

26. R.A. Bell, G.G. Christoph, F.R. Fronczek, R.E. Marsh, Science 190, 151-152 (1975).

27. B. Dietrich, M.W. Hosseini, J.-M. Lehn, R.B. Sessions, Helv. Chim. Acta 68, 289-299 (1985).

28. a) J.-M. Lehn, E. Sonveaux, A.K. Willard, J. Am. Chem. Soc. 100, 4914-4916 (1978); b) B. Dietrich, J. Guilhem, J.-M. Lehn, C. Pascard, E. Sonveaux, Helv. Chim. Acta 67, 91-104 (1984).

29. R.J. Motekaitis, A.E. Martell, I. Murase, J.-M. Lehn, M.W. Hosseini, Inorg. Chem. 27, 3630-3636 (1988).

30. M.W. Hosseini, J.-M. Lehn, Helv. Chim, Acta 749-755 (1988).

31. B. Dietrich, J.-M. Lehn, J. Guilhem, C. Pascard, Tetrahedron Lett. 30, 4125-4128 (1989).

32. D. Heyer, J.-M. Lehn, Tetrahedron Lett. 27, 5869-5872 (1986). 
33. a) J. Jazwinski, J.-M. Lehn, D. Lilienbaum, R. Ziessel, J. Guilhem, C. Pascard, J. Chem. Soc. Chem. Commun. 1691-1694 (1987); b) J.-M. Lehn, R. Méric, J.-P. Vigneron, I. Bkouche-Waksman, C. Pascard, J. Chem. Soc., Chem. Commun. 62-64 (1991).

34. E. Graf, J.-M. Lehn, J. Am. Chem. Soc. 27, 5022-5024 (1975); E. Graf, J.-M. Lehn, Helv. Chim. Acta 64, 1040-1057 (1981).

35. E. Graf, J.-M. Lehn, J. Am. Chem. Soc. 98, 6403-6405 (1976).

36. B. Metz, J.M. Rosalky, R. Weiss, J. Chem. Soc. Chem. Comm. 533-534 (1976).

37. J.P. Kintzinger, J.-M. Lehn, E. Kauffmann, J.L. Dye, A.I. Popov, J. Am. Chem. Soc. 105, 75497553 (1983); M.W. Hosseini, J.P. Kintzinger, J.-M. Lehn, A. Zahidi, Helv. Chim. Acta 72, 10781083 (1989).

38. G. Wipff, J.M. Wurtz, New J. Chem. 13, 807-820 (1989).

39. a) F.P. Schmidtchen, Chem. Ber. 113, 864-874 (1980); b) ibid 114, 597-607 (1981); F.P. Schmidtchen Angew. Chem. 89, 751-752 (1977); c) F.P. Schmidtchen, G. Müller, J. Chem. Soc.. Chem. Commun. 1115-1116 (1984).

40. F.P. Schmidtchen, J. Am. Chem. Soc. 108, 8249-8255 (1986); F.P. Schmidtchen, Tetrahedron Lett. 27, $1987-1990$ (1986).

41. M.W. Hosseini, J.-M. Lehn, Helv. Chim. Acta 71, 749-756 (1988)

42. E. Kimura, J. Incl. Phen. Mol. Recogn. Chem. 7, 183-191 (1989).

43. B.C. Askew, Tetrahedron Lett. 31, 4245-4248 (1990).

44. J.H. Hurley,A.M. Dean,J.L. Sohl, D.E. Koshland,Jr., R.M. Stroud, Science 249, 1012-1016 (1990); B.J. Calnan, B. Tidor, S. Biancalana, D. Hudson, A.D. Frankel, Science 252, 1167-1171 (1991).

45. a) B.Dietrich, T.M. Fyles, J.-M. Lehn, L.G. Pease, D.L. Fyles, J. Chem. Soc.. Chem. Commun. 934-936 (1978); b) B. Dietrich, D.L. Fyles, T.M. Fyles, J.-M. Lehn, Helv. Chim. Acta 62, 27632787 (1979).

46. a) G. Müller, J. Riede, F.P. Schmidtchen, Angew. Chem. Int. Ed. Engl. 27, 1516-1518 (1988); b) A. Echavarren, A. Galan, J. de Mendoza, A. Salmeron, J.-M. Lehn, Helv. Chim. Acta 71, 685-693 (1988); H. Kurzmeier, F.P. Schmidtchen, J. Org. Chem. 55, 3749-3755 (1990); A. Gleich, F.P. Schmidtchen, Chem. Ber. 123, $907-915$ (1990); c) A. Echavarren, A. Galan, J.-M. Lehn, J. de Mendoza, J. Am. Chem. Soc. 111, 4994-4995 (1989); A. Galan, E. Pueyo, A. Salmeron, J. de Mendoza, Tetrahedron Lett. 32, 1827-1830 (1991); d) F.P. Schmidtchen, Tetrahedron Lett. 30, 44934496 (1989); e) A. Galan, D. Andreu, A.M. Echavarren, P. Prados, J. de Mendoza, J. Am. Chem. Soc. 114, 1511-1512 (1992).

47. J.W. Pflugrath, F.A. Quiocho, J. Mol. Biol. 200, 163-180 (1988); H. Luecke, F.A. Quiocho, Nature 347, 402-406 (1990).

48. a) E. Kimura, M. Kodama, T. Yatsunami, J. Am. Chem. Soc. 104, 3182-3187 (1982); b) E. Kimura, H. Anan, T. Koike, M. Shiro, J. Org. Chem. 54, 3998-4000 (1989); c) R.A. Pascal, J. Spergel, D. Van Engen, Tetrahedron Lett. 27, 4099-4102 (1986); d) P.D. Beer, D. Hesek, J. Hodacova, S.E. Stokes, J. Chem. Soc. Chem. Commun. 270-272 (1992).

49. a) Y. Azuma, M. Newcomb, Organometallics 3, 9-14 (1984); M. Newcomb, M.T. Blanda, Y. Azuma, T.J. Delord, J. Chem. Soc., Chem. Commun. 1159-1160 (1984); b) M. Newcomb, A.M. Madonik, M.T. Blanda, J.K. Judice, Organometallics 6 , 145-150 (1987); c) M. Newcomb, J.H. Horner, M.T. Blanda, J. Am. Chem, Soc. 109, $7878-7879$ (1987); d) M. Newcomb, M.T. Blanda, Tetrahedron Lett. 29, 4261-4264 (1988); e) M. Newcomb, J.H. Horner, M.T. Blanda, P.J. Squattrito, J. Am. Chem. Soc. 111, 6294-6301 (1989); f) M.T. Blanda, J.H. Horner, M. Newcomb, J. Org. Chem. 54, 46264636 (1989); g) M.T. Blanda, M. Newcomb, Tetrahedron Lett. 30, 3501-3504 (1989).

50. a) H.E. Katz, J. Org. Chem. 50, 5027-5032 (1985); b) H.E. Katz, Organometallics 6 , 1134-1136 (1987); c) H.E. Katz, J. Am. Chem. Soc, 108, 7640-7645 (1986).

51. M.E. Jung, H. Xia, Tetrahedron Lett. 29, 297-300 (1988).

52. X. Yang, C.B. Knobler, M.F. Hawthorne, Angew. Chem. Int. Ed. Engl. 30, 1507-1508 (1991).

53. a) T.M. Fyles, Bioorganic Chemistry Frontiers, Vol. 1, p. 71, Springer Verlag, 1990; b) I. Tabushi, Y. Kobuke, J.-I. Imuta, J. Am. Chem. Soc. 103, 6152-6157 (1981); I. Tabushi, Y. Kobuke, J. Imuta, Nucleic Acids Res. Symp. Ser. 11, 249-252 (1982); c) T. Li, F. Diederich, J. Org. Chem. 57, 3449-3454 (1992)

54. a) H. Tsukube, Tetrahedron Lett. 24, 1519-1522 (1983); J. Chem. Soc. Perkin Trans. I, $615-619$ (1985); b) B. Dietrich, T.M. Fyles, M.W. Hosseini, J.-M. Lehn, K.C. Kaye, J. Chem. Soc. Chem. Commun. 691-692 (1988); c) Y. Umezawa, M. Kataoka, W. Takami, E. Kimura, T. Koike, H. Nada, Anal. Chem. 60, 2392-2396 (1988).

55. a) M.W. Hosseini, J.-M. Lehn, M.P. Mertes, Helv. Chim. Acta 66, 2454-2466 (1983); M.W. Hosseini, J.-M. Lehn, L. Maggiora, K. B. Mertes, M.P. Mertes, J. Am. Chem. Soc. 109, 537-544 (1987); b) M.W. Hosseini, J.-M. Lehn, J, Chem. Soc. Chem. Commun. 1155-1157 (1985); c) F.P. Schmidtchen, Topics in Current Chemistry 132, 101-133 (1986); F.P. Schmidtchen, A. Gleich, A. Schummer, Pure and Appl. Chem. 61, 1535-1546 (1989).

56. C. Oriol-Audit, M.W. Hosseini, J.-M. Lehn, Eur. J. Biochem. 151, 557-559 (1985).

57. E. Kimura, A. Watanabe, H. Nihira, Chem. Pharm. Bull, 31, 3264-3268 (1983).

58. J.-M. Lehn, Perspectives in Coordination Chemistry, p. 447, VCH (1992). 